\title{
Policy implementation of Mapalus kamtibmas in Minahasa Regency
}

\author{
$1^{\text {st }}$ Thelma Wawointana \\ Public Administration Study Program \\ Faculty of Social Science \\ Universitas Negeri Manado \\ Manado, Sulawesi Utara \\ thelmawawointana@unima.ac.id
}

\begin{abstract}
The emergence of a variety of public order and security issues (kamtibmas) in Minahasa Regency as criminal actions prove that the crime rate was increasing in view of the quantity and quality of crime. This research aims to determine the implementation of the policy of North Sulawesi Governor Regulation No. 8 Year 2012 on the Establishment of the Forum Mapalus kamtibmas, as well as the supporting factors and inhibiting factors. This type of research is qualitative with case study approach. The research finding showed that the policy of Governor Regulation No. 8 Year 2012 on the Establishment of the Forum Mapalus kamtibmas not been implemented in line with expectations. This can be seen with the institutionalization of the mapalus taken from the values of local wisdom of the Minahasa society should be able to foster unity and cooperation of the three institutions that merged into one forum called Mapalus kamtibmas that is the Government, Police, Military Community together with society but the fact has not been implemented well. The factors that influence the policy implemented Mapalus kamtibmas is the lack of communication, coordination, resource owned and the budget less transparent and accompanied by an attitude of local government that is less responsive.
\end{abstract}

Keywords-Implementation, Policy, Mapalus, Public and Security Order

\section{INTRODUCTION}

Increased lawlessness forms such as murder, theft, rape, persecution frequently occur in various places in the Minahasa. Similarly, domestic violence, human trafficking (trafickhing), free sex, the circulation of pornographic films in the society is still occurs. Even other forms of violence often occur as a result of liquor such as vandalism, burning houses, racing, motorcycle gangs, fights between groups and between villages (Manado Post, July 31, 2014, Tribun Manado, October 4, 2014, Tribun Manado, November 6, 2014).

The problems above partly as a result of progress in the field of science and technology that cause weakness and loss of values and norms of public life including social organizations. The importance of maintaining traditional cultural values in society as a capital for development into government policies in tackling the various problems that exist. The need to enhance institutional capacity and performance to anticipate and mitigate disruption of public and security order as well as to minimize losses resulting from the disaster. Social interaction that takes place in a society that is highly variable. Therefore, we need a deal in the development of an institution that binds the whole community in the form of ideals and cultural values of a particular device.

Social institution not only to deal with the social impact of disasters or natural disasters but also to prevent the occurrence of the disaster. Some types of disasters that occur because many institutions are not working in the society. Horizontal conflict, religion, ethnic sectarian, intervillage is evidence that the institutional set of values, norms to maintain security and order in society, and welfare no longer function properly if not in accordance with the expected goals.

Various issues of kamtibmas mentioned above encourage North Sulawesi Province Government to stipulate North Sulawesi Governor Regulation No. 8 Year 2012 on the Establishment of the Forum Mapalus kamtibmas. Mapalus kamtibmas is a spirit of mutual cooperation, collect and involved security forces, village government/Sub with society to help each other and cooperate actively in the search for the root of the problem, to solve social problems and to find solutions in order to realize the convenience, security and public order for the implementation of development programs, government and society in the rural/urban (Governor Regulation No. 8 of 2012, article 1, paragraph 1).

Since mapalus kamtibmas program policies implemented in 2012 appear to issues with respect to policy mapalus kamtibmas. In public life, often we find a variety of issues that require the attention of all parties. This is not only because the matter concerns the joint issues, but also because of the problem requires the cooperation of all parties. The participation or public participation is critical to success in the effort to achieve the common goal of security and public order.

\section{RESEARCH METHODS}

This research was conducted in North Sulawesi Minahasa Regency. This research focused on Policy 
Implementation of Mapalus kamtibmas in Minahasa Regency. This type of research is qualitative case study approach. The case study because of its particularity (have specificity), the Minahasa culture is used as a policy in the field of security and order.

Sources of data in this research were selected by purposive sampling, including: Head of the District, the Village Head/Head of Urban Village, the police, the army and the public and the data source documentation is written materials such as Law, Regulation of the Governor, Local Government Policy, materials and archive reports considered relevant, especially documents related to the focus of research. For technical validity of the data examined using the following criteria: a) the degree of confidence; b) keteralihan; c) dependence, and certainty. Data analysis technique using an interactive model analysis.

\section{RESULTS AND DISCUSSION}

Implementation of public policy in order to achieve success, require that the implementor know what to do clearly. What are the goals and objectives of the policy must be communicated to the target group (target group) that will reduce the distortion of implementation. If the delivery of the goals and objectives of a policy is not clear, do not provide an understanding or even a policy goals and targets are not known at all by the target group, then it is likely there will be a refusal or resistance of the target group concerned. According to Anderson in Public Policy-Making [1] and in Sadhana (2014:52) [2] expressed more specifically that: "Public policies are those developed by government bodies and official" (policies developed or formulated by agencies government agencies and officials).

According to George C. Edwards III described back by [3], successful implementation of the policy is influenced by factors such as: communication, resources, disposition/attitude and organizational structure. (1) Communication, public policy implementation in order to achieve success, require that the implementor know what to do clearly; (2) Resources, in policy implementation must be supported by the resources both human resources, materials and methods, goals, objectives and policy content. Resources are an important factor for the implementation of the policy to be effective and efficient; (3) Disposition / attitude, a disposition in implementation are the characteristics, attitudes possessed by the implementor of policies, such as commitment, honesty communicative, clever and democratic nature; (4) The organizational structure.

Public policy is often understood as an instrument used by the government to solve public problems in technocratic. In a sense, the government uses rational choice approach to selecting the best alternatives to solve the problems faced by society. Public policy according to reference [4] is whatever Governments choose to do or not to do. Meaning states that any government activity either explicitly or implicitly a policy. Dye according to the policy interpretation that must be interpreted with two important things: first, that the policy should be carried out by a government agency, and secondly, the policy contains a selection done or not done by the government.
Implementation of the organizational structure policy has an important role. One of the aspects of the organizational structure is their standard operating procedures (standard operating prosedures) or so-called SOP. The function of the SOP as a guide for each implementor in the act. The organizational structure that is too long is likely to weaken oversight and meimbulkan redtape, the bureaucratic procedures are cumbersome and complex. This in turn leads to inflexible organizational activity.

Public participation is a technical process to provide opportunities and wider authority to the community to jointly solve various problems of development. This community participation is based on the level of participation (level of involvement) community in the development activity. Community participation aims to find solutions to the problems faced to be solved. Thus, opening more opportunities for communities to contribute to the implementation of development activities run more effective, efficient, and sustainable. A disposition in the implementation is characteristic, attitude held by the implementor of policies, such as commitment, honesty communicative, clever and democratic nature.

Based on various research data can be analyzed that the supposed public organization in this case the Provincial Government provides a simple map to show the general activities. The lines between the various positions it is framed to show formal interaction set. In the implementation of organizational structure policy has an important role as one of the aspects of the organizational structure is their standard operating procedures (standard operating prosedures) or so-called SOP. SOP as a guide for each implementor in the act. While the organizational structure that is too long is likely to weaken oversight and lead to bureaucracy, the bureaucratic procedures are complicated and complex that in turn causes the activity of the organization that are difficult to adjust to the circumstances.

The research found that standard operating prosedures or so-called SOP is not well understood at the structural level Kamtibmas Mapalus Forum, due to socialization even less supervision by the provincial government work effectively. Auth understood each task related agencies such as the Army, Police and Local Government. It is not related to government policies Pergub number 8 in 2012 which became the foundation of social order mapalus Forum.

View of the concept of modern democracy, public policy not only provides the spark thoughts or opinions officials who represent the people, but public opinion (public opinion) also have a portion of the same magnitude and are reflected in public policies. Every public policy should be oriented to the public interest (public interest).

Today scholars of public administration have held lengthy discussions in order to find a new dimension in providing a sense of "public" in "public administration". Understanding public in public administration no longer has traditionally meant purely institutional (like the state), but in relation to how much influence and link the institution with the public interest.

Public administrator can be distinguished by other administrators solely because he works for the public 
interest. Under no circumstances, public organizations (such as the state or government) should continue to provide the best possible service to the community (public). Corruption, fraud and abuse of power and authority, government that is not clean and so on can increase public antipathy in public organizations and in turn the people no longer trust the public so that the public bureaucracy is difficult to expect their political participation.

Society has been pinning its hopes on the public administrator, namely the expectation that they always provide the best possible service to the public. To be a public servant who always pay attention to the public interest, the public administrator needs to have kepublikan spirit (the spirit of publicness). The spirit of administrative and political responsibility should be attached also to the public administrator himself, so that he can run with good professional role.

Based on the above it is clear that the public organizations and the public administrator rnempunyai administrative and political responsibilities. In connection with that, then to carry out the responsibilities of both the public administrator should be able to connect between the public interest in public policy formulation. The main task of public administrators have a close relationship with the public interest, but unfortunately rarely do they know the theory about the public interest. Furthermore Harmon (1986) suggests a model of public policy making that show public relations administrator role (as the formulator of public policy) with the public interest (4) Model formulation of policies on administrator Harmon describes the involvement of both implicitly and explicitly in the selection of public policy, as indicated by the level of connection or relationship between a public policy with the public interest.

Public policy is often understood as an instrument used by the government to solve public problems in technocratic. In a sense the government uses rational choice approach to selecting the best alternatives to solve the problems faced by society. Public policy in the definition of Dye is whatever Governments choose to do or not to do. Dye came to reveal meaning that any government activity either explicitly or implicitly a policy. Dye policy interpretation according to the above should be interpreted with two important things: first, that the policy should be carried out by a government agency, and secondly, the policy contains a selection done or not done by the government.

The policy has almost the same meaning with regulations / legislation or political / power, government decisions, programs or models. 1) The meaning of the word "policy" or "wisdom" in the dictionary of EnglishIndonesian means "wisdom", but in the Science of Government or political science, policy can be likened it means by "policy". While "policy" in greater depth can not be translated into Indonesian, because the "policy" is not the policy or wisdom, "policy" has a very positive nature, whereas the policy or policies may have the nature of positive and negative can. Policy / wisdom is defined as a decision by the competent authority or influenced by any particular political system and would serve as guidelines in the system or program to achieve certain goals. Therefore, the following is the definition of public policy by some experts.
Public policy is a course of action proposed by a person, group or government in a given environment are on the barriers and opportunities against the proposed policy for the use and overcome in order to achieve a goal or realize a goal or a purpose. Public policy should contain objectives, values and social practices that exist in society. Public policy is seen as a process and the process is seen as a simple model to understand the constellation between actors and interactions that take place in it. That basically no difference between the concepts of policy and expediency.

Is a series of policy alternatives ready to be selected based on certain principles. While discretion with regard to a decision to allow something which is prohibited by specific reasons such as humanitarian considerations, an emergency and others. Policy is a result of an exhaustive analysis of the various alternatives that lead to decisions about the best alternative. While the wisdom of always implies abuse everything that has been designated for a specific reason. Wisdom is the embodiment of the rules that have been defined according to the situation and the local situation by the officials authorized person, with different definitions of the above, then it should be in implementation are also different.

Public policy is a series of choices that are interconnected created by agencies or government officials in areas related to government functions, such as security and defense, energy, healthcare, education, public welfare, crime, urban and others.

As the policy has broad meaning and multiple interpretations. For example, James Anderson gives meaning the behavior of actors in the policy as a particular field of activity. The definition above is very spacious and can mean many things, for example, the actor may be individuals or organizations; to governmental and nongovernmental. Similarly, the term could be interpreted certain activities administrative activities, political, economic and others. In addition, any of the activities spacious and multi interpretation can be for example the achievement of goals, plans, programs, and so on. Thus, a policy study is the study of the behavior of different actors in various fields of activities that have relevance to the role of someone.

Factors that influence policy implementation mapalus kamtibmas namely:

\section{Communication}

Public policy implementation in order to achieve success, require that the implementor know what to do clearly. What are the goals and objectives of the policy must be communicated to the target group (target group) that will reduce the distortion of implementation. If the delivery of the goals and objectives of a policy is not clear, do not provide an understanding or even a policy goals and targets are not known at all by the target group, then it is likely there will be a refusal or resistance of the target group concerned.

Kambtinmas Mapalus policy is weak in the communication in this regard socialization, so the lack of understanding of the implementor and the public about the program mapalus kamtibmas caused due to the socialization process performed poorly. Governments are less aware of the importance of communication is an important stage in 
the implementation of policies is an important stage in the policy.

2. Resources

Human Resources(SDM) is one very important factor that can not even be released from an organization or an institution. People who have the resources employed in an organization as a driver for achieving objectives of the organization or institution. The success of an organization or institution is determined by the human resources that exist in it. The human resources that serve as the executive in an organization must understand the tasks, goals and objectives and responsibilities.

In order for policy implementation goes well then it must be supported by the resources both human resources, materials and methods, goals, objectives and policy content. Although it has been communicated clearly and consistently, but if the implementor lack the resources to carry out implementation will not be effective and efficient. Resources are an important factor for the implementation of the policy to be effective and efficient. Without resources, the policy simply stay on paper becomes a document alone is not realized to provide solving problems in society and efforts to provide services to the public.

Data were obtained above were competency of mapalus kamtibmas forum there are competent but do not carry out the task, and others said it is not in accordance with the expected competencies for a role not yet optimal. Even though they mimiliki competence but in fact they do not perform well because there are other tasks to be done, in addition to the limitations both of bhabinkamtibmas personnel and of babinsa.

Limited human resources that serve as the executor mapalus kamtibmas an obstacle in the implementation of mapalus kamtibmas. For example, frequent personnel changes due to mutations in a job, or get a new position somewhere else. This is evident from the lack of good personnel and babinsa bhabinkamtibmas in Minahasa regency. Policy implementation should be supported by the resources, both human resources, materials and methods, goals, objectives and policy content despite being communicated clearly and consistently, but if the implementor lack the resources to carry out implementation will not be effective and efficient.

Human resources are placed on the structure of the forum mapalus less capable and professional. Supporting material resources, facilities such as incomplete secretariat with administrative support equipment such as computers, desks, vehicle operation, not the maximum available. Limited human resources that serve as the executor mapalus kamtibmas good looks of a lack of personnel and babinsa bhabinkamtibmas, as well as the lack of involvement of the community.

\section{Disposition / Attitude}

Commitment is an agreement (attachment) to do something. The commitment can be interpreted also as a spoken agreement a person to yourself or to others to be fulfilled and implemented. Involvement in employment means favoring certain work of an individual, while a high organizational commitment means favoring organizations that recruit such individuals. Forum mapalus social order was dealing directly with the public, then as executive kamtibmas mapalus Forum in carrying out its duties should be able to implement these policies with the goals of mapalus kamtibmas and has a strong commitment to his task.

Commitment owned by the government: either the provincial government as supervisor, district/city government as a supervisor, the district government as a controller and the village government as the executive in carrying out responsibilities in accordance gubernatorial kamtibmas mapalus program. No. 8 Year 2012. Based on the results of the research data it is clear that a commitment which is owned by the government both provincial government as supervisor, district / city government as a supervisor, the district government as controller and village heads and village heads as executor in mapalus forum kamtibmas then in carrying out responsibilities responsible for the program in accordance gubernatorial mapalus kamtibmas. No. 8 Year 2012 is not truly committed. Weak commitment by the government because that impressed policies that simply building where the weakness in policy formulation and implementation. Similarly, the attitude of community leaders who are indifferent.

The involvement of all members of this forum should facilitate mapalus kamtibmas solving also be key to the success of this policy. However ketelibatan mapalus kamtibmas community forums are very less. Due to the limitations of security personnel, as well as babinsa bhabinkamtibmas consequently less active role in carrying out its duties. In addition, in the process of policy implementation there are obstacles that should be a concern of government such as funding and operational facilities. How the policy will work well when there is no support from the government. Surely if this constraint is not observed then this policy will not run properly

\section{Structure}

Public policy is often understood as an instrument used by the government to solve public problems in technocratic. In a sense the government uses rational choice approach to selecting the best alternatives to solve the problems faced by society. By reference [5] Public policy is whatever Governments choose to do or not to do. Dye came to reveal meaning that any government activity either explicitly or implicitly a policy. Dye according to the policy interpretation that must be interpreted with two important things: first, that the policy should be carried out by a government agency, and secondly, the policy contains a selection done or not done by the government.

Implementation of policies through organizational structure plays an important role. One of the aspects of the organizational structure is their standard operating procedures (standard operating prosedures) or so-called SOP. The function of the SOP as a guide for each implementor in the act. The organizational structure that is too long is likely to weaken oversight and meimbulkan redtape, the bureaucratic procedures are cumbersome and complex. This in turn leads to inflexible organizational activity. Public organizations in this case the Provincial Government should provide a simple map to show the general activities from top to bottom. The lines between the various positions it is framed to show formal interaction set. In the implementation of organizational structure policy has an important role. One of the aspects of the organizational structure is their standard operating procedures (standard 
operating prosedures) or so-called SOP. The function of the SOP as a guide for each implementor in the act. The organizational structure that is too long is likely to weaken oversight and meimbulkan red-tape, the bureaucratic procedures are cumbersome and complex. This in turn leads to inflexible organizational activity.

The study found that standard operating prosedures or so-called SOP is not well understood at the structural level Kamtibmas Mapalus Forum, due to socialization even less supervision by the provincial government work effectively. Auth understood each task related agencies such as the Army, Police and Local Government. It is not related to government policies Pergub number 8 in 2012 which became the foundation of social order mapalus Forum. The structure of social order in the village mapalus forum/village have until now never functioned. There was even a village/urban villages that do not yet have mapalus kamtibmas forum structure in accordance with the gubernatorial regulation.

\section{CONCLUSION}

Kamtibmas Mapalus policy implementation does not go well because there are four factors that is crucial that the communication factor, resources, executive attitudes, and structure orgganisasi, Thus according the findings of the communication factor in this process mapalus policy dissemination of social order did not go well. Thus the lack of understanding of the implementor and the public about the program mapalus kamtibmas. Governments are less aware of the importance of communication is an important stage in the implementation of the policy. This stage determines whether the policies pursued by the government is really aplikabel in the field and successfully. Socialization is good, it will generate outputs and outcomes as planned.

Implementation of policies should be supported also by factors of resources both human resources, materials and methods, goals, objectives and policy content. Although it has been communicated clearly and consistently, but if the implementor lack the resources to carry out implementation will not be effective and efficient. Resources are an important factor for the implementation of the policy to be effective and efficient. Without resources, the policy simply stay on paper becomes a document only and are not optimized to provide solving problems in the community and provide services to the community. The findings obtained can be concluded that human resources are placed on the structure mapalus forum kamtibmas less capable and professional. Then, from the supporting material resources,
Attitude or government commitment so impressed policies origin where the weakness in policy formulation and implementation. The attitude of community leaders were indifferent became the study's findings, although there are also community leaders who care about such as religious figures, but these figures are less involved in kamtibmas forum. Public attitudes about participating because of weak government role in disseminating that people's attitudes tend to be passive.

The organizational structure has an important role. One of the aspects of the organizational structure is their standard operating procedures (standard operating prosedures) or so-called SOP. The function of the SOP as a guide for each implementor in the act. The organizational structure that is too long is likely to weaken oversight and meimbulkan red-tape, the bureaucratic procedures are cumbersome and complex. This in turn leads to inflexible organizational activity

Based on the indicators above concluded that in order to implement a policy such as the establishment of a forum mapalus social order was adopted from local culture to be institutionalized need to pay attention to communication, resources, disposition, and structure so that the policy can be implemented well as factors institutionally that affect the strength and weaknesses of the role Mapalus to maintain security and public order.

\section{ACKNOWLEDGMENT}

The author would like to say thank Dean of Social Science Faculty of Manado State University.

\section{REFERENCES}

[1] A. James, "Public Policy Making," New York, Praegger, 1975.

[2] K. Sadhana, Realitas Kebijakan publik. Malang: UM Press, 2012

[3] R. Nugroho, "Public Policy: Dinamika Kebijakan, Analisis Kebijakan, Manajemen Kebijakan," Jakarta Elex Media Komputindo, 2011.

[4] T. R. Dye, Understanding of Public Policy. New Jersey: Prentice Hall, 1996.

[5] T. R. Dye and T. R. Dye, Understanding public policy. Prentice Hall Englewood Cliffs, NJ, 1992. 